University of Nebraska - Lincoln

DigitalCommons@University of Nebraska - Lincoln

Sociology Department, Faculty Publications

Sociology, Department of

2005

\title{
Arrests Among Homeless and Runaway Youths: The Effects of Race and Gender
}

Kevin A. Yoder

University of North Texas

Ed A. Muñoz

University of Wyoming

Les B. Whitbeck

University of Nebraska-Lincoln, Iwhitbeck2@unl.edu

Dan R. Hoyt

University of Nebraska-Lincoln, dhoyt2@unl.edu

Barbara J. McMorris

University of Washington - Tacoma Campus

Follow this and additional works at: https://digitalcommons.unl.edu/sociologyfacpub

Yoder, Kevin A.; Muñoz, Ed A.; Whitbeck, Les B.; Hoyt, Dan R.; and McMorris, Barbara J., "Arrests Among Homeless and Runaway Youths: The Effects of Race and Gender" (2005). Sociology Department, Faculty Publications. 215.

https://digitalcommons.unl.edu/sociologyfacpub/215

This Article is brought to you for free and open access by the Sociology, Department of at DigitalCommons@University of Nebraska - Lincoln. It has been accepted for inclusion in Sociology Department, Faculty Publications by an authorized administrator of DigitalCommons@University of Nebraska - Lincoln. 
Published in Journal of Crime and Justice 28:1 (2005), pp. 35-58;

doi: 10.1080/0735648X.2005.9721206

Copyright (C) 2005 Routledge/Taylor \& Francis. Used by permission.

The Midwest Homeless and Runaway Adolescent Project was supported by the National Institute of Mental Health (MH50140), Les B. Whitbeck, Principal Investigator. The authors thank Lisa Thane and the anonymous reviewers for Journal of Crime and Justice for comments on earlier drafts of this paper.

\title{
Arrests Among Homeless and Runaway Youths: The Effects of Race and Gender
}

\author{
Kevin A. Yoder \\ University of North Texas \\ Ed A. Muñoz \\ University of Wyoming \\ Les B. Whitbeck \\ University of Nebraska-Lincoln \\ Dan R. Hoyt \\ University of Nebraska-Lincoln \\ Barbara J. McMorris \\ University of Washington
}

\begin{abstract}
This study examined the contributions of race and gender to the likelihood of a first post-run arrest for a more serious and less serious offense in a sample of homeless and runaway youths from four Midwestern states. Event history analysis was used to test the hypothesis that
\end{abstract}


race and gender would interact so that the likelihood of a first post-run arrest for a more serious and less serious offense would be highest for non-white males and non-white females, respectively. Potentially confounding factors - deviant subsistence strategies, substance use, gang involvement and membership, prior arrests, age, prior physical abuse, age on own, and spending time on the street-were controlled in the analyses. The hypotheses regarding the interaction of race and gender were not supported by the data. Non-whites were more likely than whites, and males were more likely than females, to be arrested for a more serious offense, and white females were more likely than non-white females to be arrested for a less serious offense.

\section{Introduction}

Homeless and runaway youths often engage in delinquent or criminal behaviors to survive on the streets (Baron \& Hartnagel, 1998; Hagan \& McCarthy, 1997; McCarthy \& Hagan, 1992a, 1992b). McCarthy and Hagan (1992b) reported that 40 to $50 \%$ of the 390 homeless young people in their study stole food or other goods and $30 \%$ had engaged in prostitution. Whitbeck and Simons (1993) studied a sample of 156 homeless youths, and they found that $63 \%$ had shoplifted, 32\% broke in and took things from a house or store, $19 \%$ took money or something from somebody by force, and $9 \%$ sold sexual favors. Finally, in a sample of 752 street youths, Kipke and colleagues (Kipke et al., 1997) discovered that $30 \%$ had stolen, $32 \%$ dealt drugs, and $46 \%$ engaged in prostitution.

In addition, many homeless and runaway youths have had contact with law enforcement officials and the juvenile justice system. In a sample of 118 homeless and runaway youths from New York City, Shaffer and Caton (1984) reported that 37\% of males and 19\% of females had been charged with an offense. McCarthy and Hagan (1992b) noted that $45.5 \%$ of the homeless young people in their sample had been incarcerated at least one time since being on the street. Moreover, when comparing their sample of homeless youths to a sample of 562 school youths, Hagan and McCarthy (1994) found that the homeless youths were much more likely than the school youths to have been picked up or charged by the police. Finally, in a 20-year longitudinal cohort study of 1,196 people, Kaufman and Widom (1999) reported that people who had run away prior to age 18 were more likely than those who did not run away to be arrested as a juvenile.

The aforementioned studies have documented the extent to which homeless and runaway youths engage in delinquent or criminal behaviors and encounter law enforcement officials, but researchers have 
paid little attention to the nature of law enforcement encounters with youths in this high-risk population. More specifically, research has not demonstrated the extent to which race and gender contribute to the risk of arrest among homeless and runaway youths. More generally, relatively few studies of non-runaway youths have examined the effects of race and gender on the likelihood of arrest (Black \& Reiss, 1970; Conley, 1994; Horowitz \& Pottieger, 1991; Lundman et al., 1978; Piliavin \& Briar, 1964; Wordes \& Bynum, 1995), and the results have been inconsistent (Horowitz \& Pottieger, 1991; McCord et al., 2001). The present study examines the contributions of race and gender to the likelihood of a first post-run arrest for a more serious or less serious offense in a sample of homeless and runaway youths from four Midwestern states.

\section{Race, Gender, and Arrests}

Researchers have studied the extent to which involvement in delinquent or criminal activities versus biases among law enforcement officials contributes to the disproportionate arrests of racial/ethnic minority youths (McCord et al., 2001). In some studies of racial inequality in the juvenile justice system, researchers failed to find any systematic bias against minority (usually African-American) young people, and it was argued that higher arrest rates resulted from their disproportionate involvement in delinquent or criminal activities (Blumstein \& Graddy, 1982; Hindelang, 1978; Krisberg et al., 1987). Other researchers, however, have reported biases against minority youths in arrest decisions that are not due to differential involvement in delinquency or criminal activities or the types of offenses committed (Conley, 1994; Engen et al., 2002; Huizinga \& Elliot, 1987; Wordes \& Bynum, 1995).

Researchers have also studied the extent to which delinquent or criminal behaviors and arrest rates differ by gender. Years of research suggest that delinquent and criminal behaviors are most prevalent among young males, and studies show that young males are more likely than young females to be arrested for serious crimes (Blumstein \& Graddy, 1982; Huizinga \& Elliot, 1987; Krisberg et al., 1987; Zimring, 1998). Nevertheless, young females are more likely than young males to be arrested for two types of offenses: shoplifting and non-criminal status offenses (e.g., running away, truancy, or needing supervision) (Chesney-Lind, 1977; Chesney-Lind \& Shelden, 1998; Zimring, 1998). Young females may be disproportionately arrested for status offenses because of paternalistic attitudes on the part of law enforcement officials (Chesney-Lind, 1977). 
Researchers have also noted that race/ethnicity and gender interact to affect the likelihood of arrest. Law enforcement officials are concerned about potential danger, and they develop mental categorizations of symbolic assailants. Symbolic assailants are individuals who are identified by appearance, gesture, and/or language whom law enforcement officials deem apparent harbingers of potential danger. People who fit the mental categorization are at higher risk for interrogation and/or arrest, regardless of any observed delinquent or criminal behavior (Skolnick, 1966). Law enforcement officials have labeled and categorized young non-white males as criminally prone (Piliavin \& Briar, 1964). In addition, non-white female criminality has become racialized over the years. Some evidence suggests that young non-white females are more likely than young white females to be arrested, and this might reflect both paternalistic feelings and racial biases on the part of law enforcement officials (Horowitz \& Pottieger, 199 1; Visher, 1983).

The aforementioned arguments regarding the interaction of race/ethnicity and gender suggest two hypotheses that will be investigated in this paper. First, it is hypothesized that the likelihood of a first post-run arrest for a more serious offense will be highest for non-white males. Second, it is hypothesized that the likelihood of a first post-run arrest for a less serious offense will be highest for non-white females.

\section{Other Factors Related to Arrests}

Several factors may confound the relationships of race/ethnicity and gender with the likelihood of arrests among youths, and these factors are included in the analyses. The first factor is involvement in delinquent or criminal activities. Studies of arrests among youths incorporate variables that measure the type of offense committed (e.g., Black \& Reiss, 1970; Lundman et al., 1978; McCord et al., 2001; Visher, 1983), general involvement in delinquent or criminal activities (e.g., Hagan \& McCarthy, 1994), or use of illegal drugs specifically (e.g., Horowitz \& Pottieger, 1991) and these variables are significant predictors of the likelihood of arrest.

A second factor consists of gang involvement and membership. Youth gang members are at increased risk of contact with the juvenile justice system relative to youths who are not involved with gangs (e.g., Curry, Decker, \& Egley, 2002; Johnstone, 1983). Some researchers have identified an intermediate group of youths who are involved with gangs (but not gang members), and there is evidence to suggest that the risk of arrest is higher for gang involved than for non- 
involved youths (e.g., Donnermeyer, Edwards, Chavez, \& Beauvais, 1996; Yoder, Whitbeck, \& Hoyt, 2003). Gang involvement and membership might increase the likelihood of arrest for at least two reasons. First, youths who are gang involved or gang members might be identified as criminally-prone symbolic assailants by law enforcement officials (Conley, 1994). Second, gang involvement and membership might reflect an actual increased involvement in delinquent activities, which has been demonstrated in numerous studies (e.g., Curry, Decker, \& Egley, 2002; Dukes, Martinez, \& Stein, 1997). A third factor, which is related to the first two factors and is relevant to homeless and runaway youths, consists of arrests prior to running away from home. Arrests prior to running away from home may reflect a delinquent career that begins prior to running away from home and continues when the youth is on the street, which increases the likelihood of subsequent arrests. Prior arrests may also reflect childhood conduct problems, which itself increased the likelihood of arrest in a sample of homeless adults (Desai et al., 2000). Finally, law enforcement officials may be able to check for prior arrests, and this might influence their decision to arrest a youth (Sealock \& Simpson, 1998).

A fourth factor related to the likelihood of arrests among young people is age. Empirical studies consistently report that arrest rates increase from childhood until the mid- to late-teens and then decline thereafter. In fact, this age distribution is generally invariant across time, setting, gender, and race/ethnicity (Hirschi \& Gottfredson, 1983).

A fifth factor related to the likelihood of arrests among youths is physical abuse by an adult caretaker. Hagan and McCarthy (1994) reported an indirect relationship between childhood physical maltreatment and police sanctions via homelessness (currently homeless and number of runaway episodes) in a sample of homeless youths. Family members may use physical violence to control the behavior of other family members, and children learn to control others by the use of aggressive behaviors and physical violence. This increases the likelihood of later delinquent behaviors and police sanctions (Hagan \& McCarthy, 1994).

Two other factors are related to the likelihood of arrests among homeless and runaway youths in particular. The first is time on the street. Research on homeless and runaway young people has established a positive relationship between time on the street and criminal behavior (Baron \& Hartnagel, 1998; McCarthy \& Hagan, 1992a, 1992b). In their study of homeless men, Snow and colleagues (1989) reasoned that men who were on the street for longer amounts of time risked increased exposure to police and broadened their repertoire of behaviors that would likely elicit police response. Similarly, other researchers suggest that, for homeless 
and runaway youths, a longer time on the street would provide the opportunity for increased embeddedness in criminal networks and the opportunity to commit more crimes (e.g., McCarthy \& Hagan, 1995), which then increases the likelihood of arrest.

The other factor consists of spending time directly on the street. McCarthy and Hagan (1992b) found that Canadian youths who were living directly on the street (e.g., abandoned buildings, bus or train stations) were at increased risk of incarceration relative to youths who were living in social service agencies (e.g., counseling agencies or youth hostels). Hagan and McCarthy (1994) reported a statistically significant positive relationship between homelessness and police sanctions in a sample of homeless youths. This effect is possible for at least three reasons. First, being directly on the street may reflect extreme poverty that drives youths to crime for survival (Baron \& Hartnagel, 1998; Hagan \& McCarthy, 1997). Second, being on the skeet may expose youths to more seriously delinquent youths who can provide additional criminal training (McCarthy \& Hagan, 1995). Third, being on the street makes it more likely that the youth will be seen by the police and, hence, arrested (Snow et al., 1989).

In addition, being on the street and age might interact with each other and with race and gender to affect the likelihood of arrest among homeless and runaway youths. These interactions have not been tested very extensively, but they are plausible on theoretical grounds. Youths who are on the street and younger, female, or non-white might attract more police attention, and this might increase the risk of arrest. Moreover, younger females might be at increased risk for arrest relative to older females due to paternalistic feelings on the part of police officers (Visher, 1983). Similarly, younger non-white youths may experience an increased probability of arrest relative to older non-white youths as a result of both paternalistic feelings and racial biases on the part of law enforcement officials. Finally, homeless and runaway youths might experience street crime amplification - early abuse experiences might interact with earlier police sanctions to increase the likelihood of later arrest (Hagan \& McCarthy, 1997).

\section{Method}

\section{Sample}

The Midwest Homeless and Runaway Adolescent Project (MHRAP) was a cross-sectional study of 602 homeless and runaway youths in four 
Midwestern states. Young people were interviewed on the streets, in shelters, and in drop-in centers by outreach workers affiliated with agencies that served homeless and runaway youths in Iowa, Kansas, Missouri, and Nebraska. Interviews typically lasted one and one-half hours, and the participants were given a snack and \$15 participation fee. Participants signed a statement of consent, and parental/caretaker consent was obtained in accordance with the procedures set forth by the shelters. The youths were informed of their right to refuse to participate, to refuse to answer individual questions, or to stop the interview at any time. Participation rates by agency ranged from 71 to $100 \%$, and the overall participation rate was $93 \%$. Referral and support services were offered to youths on the street and were provided to young people in the shelters, regardless of their willingness to be interviewed. The study also complied with mandatory child abuse reporting statutes.

Of the 602 youths in the MHRAP, 361 (60\%) were female. A majority (60.1\%) identified themselves as white (non-Hispanic), $24.1 \%$ as AfricanAmerican, 3.3\% as Hispanic, 2.5\% as Native American, and 10\% as biracial, multi-racial, or other. On average, these youths were 16.27 years old $(\mathrm{SD}=1.93$, range $=12$ to 22 years), and prior to running away from home, over half $(54.5 \%)$ lived in a big city (with a population of 100,000 or more) or a suburb, $29.4 \%$ lived in towns of 10,000 to 100,000 , and $14.7 \%$ lived in small towns or rural areas. The young people ran away from home for the first time when they were an average of 13.53 years old $(\mathrm{SD}=2.52$, range $=4$ to 20 years), and by the time of the interview, they had spent a median of 60.50 days on their own (range of 1 day to 7.6 years).

\section{Dependent Variables}

Youths in the MHRAP were asked how many times they had ever been arrested by the police, and if so, they were asked to provide the date (month and year) and type of offense(s) committed for their first arrest and for their four most recent arrests. Further, the youths provided the age at which they first ran away from home, and this information was used to determine when their first post-run arrest occurred (if at all). ${ }^{1}$ The offenses for the first postrun arrests were categorized into more serious and less serious offenses. More serious offenses included property damage, burglary, and personal injury; less serious offenses included shoplifting, trespassing, running away, public drunkenness, and prostitution. If the youths had been arrested for multiple offenses at one time, the most serious of the offenses was designated as the reason for the arrest. Using these categorizations, two dependent indicator variables were 
used in the analyses: Arrest for a Less Serious Offense $(1=$ first post-run arrest for a less serious offense at a given age, $0=$ not arrested for a less serious offense at a given age) and Arrest for a More Serious Offense $(1=$ first post-run arrest for a more serious offense at a given age, $0=$ not arrested for a more serious offense at a given age).

\section{Independent Variables}

The first independent variable, Deviant Subsistence Strategies, consisted of 6 items that assessed whether youths engaged in deviant subsistence strategies while on their own (taking money from someone, breaking in and taking things from a store or house, drug dealing, stealing or shoplifting food, and prostituting for money or for food). Response categories on individual items were $0=$ no and $1=$ yes. The items were summed so that higher values indicated more deviant subsistence strategies, and Cronbach's alpha for the 6 items was .71. The distribution of the summed scale was positively skewed, and the square root of the scale was used in the analyses.

Second, Substance Use consisted of 11 classes of substances that the youths might have used in the year prior to the interview (beer, hard liquor, marijuana, crank, other amphetamines such as speed and crystal meth, cocaine (including crack), opiates, hallucinogens such as LSD, tranquilizers such as Valium, barbiturates such as quaaludes, and inhalants such as paint or glue). Response categories on individual items ranges from $0=$ never to $6=$ daily. The items were summed so that higher values indicated more substance use, and Cronbach's alpha for the 11 items was .86. As with Deviant Subsistence Strategies, the distribution of the summed scale was positively skewed, and the square root of the scale was used in the analyses.

Third, Gang was created from four questions (each having response categories of $1=$ yes, $2=$ no): Have you ever participated in gang activity? Have you ever been asked to join a gang? Have you ever been through a gang initiation? Do you belong to a gang now? Based on the responses to these four questions, two indicator variables were created: Involved $(1=$ answered yes to at least one of the first three questions but answered no to the fourth, $0=$ otherwise $)$ and Member ( $1=$ answered yes to all four questions, $0=$ otherwise). The remaining group, No Involvement (i.e., those who answered no to all four questions), was the reference category in the analyses.

Fourth, Prior Arrests was an indicator variable that measured whether a youth had ever been arrested prior to running away from home for the first time. Response categories were $0=$ the youth had not 
been arrested prior to running away from home for the first time and $1=$ the youth had been arrested at least one time prior to running away from home for the first time.

Fifth, Age was a continuous measure of the youth's age in years. A quadratic age term, $\mathbf{A g e}^{2}$, was included to test for a curvilinear relationship between age and the likelihood of arrest. As a strategy for reducing collinearity between the linear and quadratic age term, the linear term was first centered, and the quadratic term was computed from that centered variable (e.g., Aiken \& West, 1991; Kleinbaum et al., 1998). ${ }^{2}$

Sixth, Prior Physical Abuse consisted of seven items adapted from the Conflict Tactics Scale (CTS; Straus, 1979) that measured physical abuse prior to running away from home. Youths reported whether an adult caretaker had thrown something at them; pushed, shoved, or grabbed them; slapped them; hit them with an object; beat them up; threatened them with a weapon; or wounded them with a weapon. Response categories on individual items were $0=$ no and $1=$ yes. The items were summed so that higher values indicated more physical abuse. Researchers have provided evidence for validity and reliability of scores on the CTS in other samples (e.g., Straus, 1979), and in the present sample, Cronbach's alpha was 75 .

Seventh, Age on Own was a continuous measure of the age (in years) at which the youths first ran away from home, and it is used as a proxy variable for the amount of time on the street. ${ }^{3}$

Eighth, On the Street was an indicator variable that measured whether a youth had spent time directly on the street (e.g., sleeping outside or in an abandoned building). Response categories were $0=$ did not spend time on the street at a given age and $1=$ spent time directly on the street at a given age. Youths in the MHRAP completed a Life Events Matrix in which they listed every living situation, including the dates begun and ended, that they had experienced since birth. The dates were converted to the youth's ages, and if at a given age the youths indicated that he or she had spent time directly on the street, On the Street was coded as 1 for that age.

Finally, Race was an indicator variable representing the race of the youth $(0=$ white and $1=$ non-white [African-American, Hispanic, Native American, bi-racial, multi-racial, or other]), and Gender was an indicator variable representing the gender of the youth $(0=$ female, $1=$ male $)$.

\section{Analytic Strategy}

Discrete-time event history analysis was used to analyze the relationships between the independent and dependent variables (Allison, 1984; 
Singer \& Willett, 1993). This method uses person-year data sets in which data is provided at each time point (every year) until an event is experienced (first post-run arrest) or is right-censored at the time of the interview (no arrest occurs prior to the interview). Person-year data sets were constructed separately, based on retrospective reports of the youth, for each arrest outcome beginning with the year that the youth first ran away from home and ending with the year of the first post-run arrest (if arrested) or the year of the interview (if not arrested). The data sets included both time-varying (i.e., Age and On the Street) and time-invariant (Deviant Subsistence Strategies, Substance Use, Gang, Prior Arrests, Prior Physical Abuse, Age on Own, Race, and Gender) predictors, and the data sets were constructed under the "competing risks" assumption (Allison, 1984). ${ }^{4}$

Logistic regression models using the person-year data sets were estimated for both dependent variables, and the analyses were conducted in three steps. First, models were estimated with the main effects (plus $\mathrm{Age}^{2}$ ) of all the independent variables. Second, the interaction effects discussed in the literature review (Race by Gender; On the Street by Age, $\mathrm{Age}^{2}$, Race, and Gender; Age and $\mathrm{Age}^{2}$ by Race and Gender; and Prior Physical Abuse by Prior Arrests) were tested one at a time by entering them into separate models controlling for the main effects of all the other independent variables. ${ }^{5}$ In the final step, the significant interactions from the previous step were included in a final model.

\section{Results}

\section{Arrest Frequencies}

Of the 602 youths in the MHRAP, $312(51.8 \%)$ were arrested at some time during their lives, $286(47.5 \%)$ were never arrested, and $4(.7 \%)$ failed to respond to the arrest questions and were excluded from subsequent analyses. Of the 312 youths who were ever arrested, 14 did not indicate when they were arrested, and they were excluded from subsequent analyses. In sum, a total of 18 young people were excluded from, and 584 were included in, subsequent analyses. The included and excluded youths did not differ significantly on any of the study variables.

Of the 298 youths for whom complete arrest records were available, 16 were arrested prior to running away from home only, and 282 were arrested after running away from home for the first time. Of these 282 youths, 229 had not been arrested prior to running away from home. Furthermore, of these 282 youths, 155 had first post-run arrests for less seri- 
ous offenses such as running away from home (33.5\% of 155), shoplifting $(17.4 \%)$, alcohol- or drug-related offenses (15.5\%), and other (33.6\%). Finally, of these 282 youths, 127 had first post-run arrests for more serious offenses such as property offenses (theft; $18.9 \%$ of 127), damage (vandalism or arson; $6.3 \%$ ), serious property offenses (burglary, armed robbery, or auto theft; $29.1 \%$ ), and injury (assault, assault with a weapon, fights, or domestic violence).

Figure 1 presents a plot of the cumulative proportion of youths who had first post-run arrests for more serious and less serious offenses. Of the youths who would experience any first post-run arrest, approximately one-half were arrested by age 14. In addition, the proportions of youths who had first post-run arrests for less serious and more serious offenses were approximately equal until age 14; thereafter, youths were more likely to be arrested for less serious than more serious offenses.

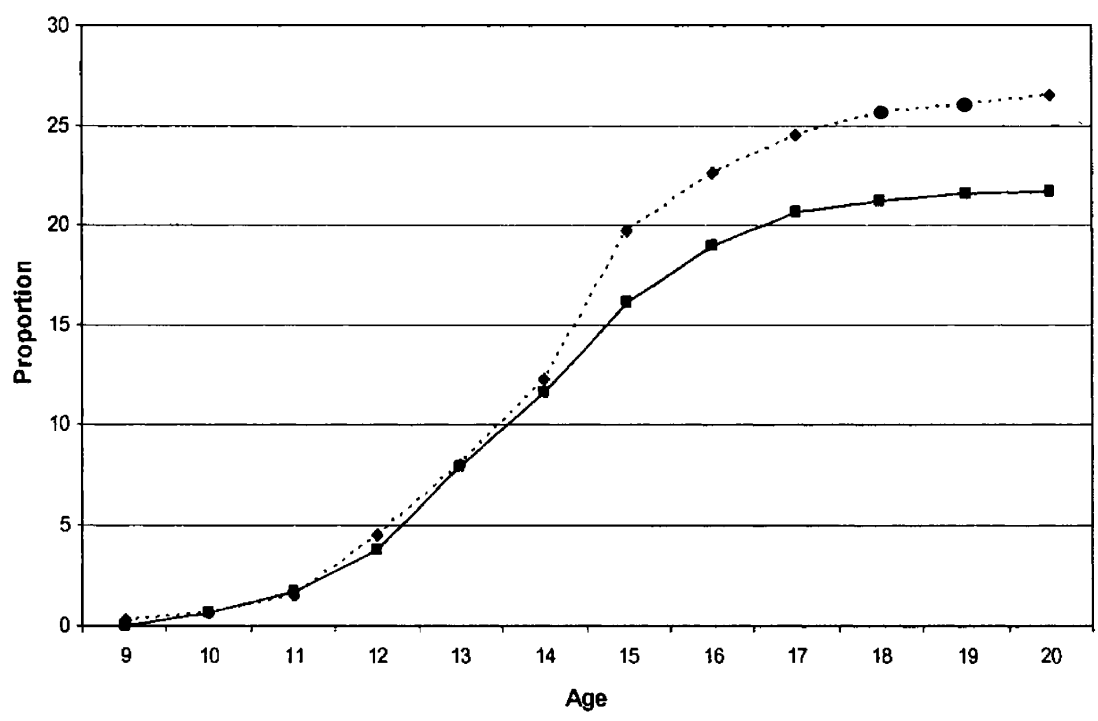

$\cdots+\cdots$ Less Serious Offense $\rightarrow-$ More Serious Offense

Figure 1. Cumulative Proportion of Youths Arrested (by Offense Type) 


\section{Event History Analysis Results}

Table 1 contains the event history analysis results. The first two columns contain the results (unstandardized coefficient estimates B and odds ratios $\mathrm{e}^{\mathrm{B}}$ ) for the model predicting Arrest for a More Serious Offense, and the last two columns contain the corresponding results for the model predicting Arrest for a Less Serious Offense. Of all the interactions tested, only the Race by Gender interaction was statistically significant in the model predicting Arrest for a Less Serious Offense. Both multivariate models fit the data better than did models with just the intercept term (-2 $\log$ likelihood statistics of 70.88 and 74.05, $d f^{\prime} \mathrm{s}$ of 12 and 13, $\left.p^{\prime} \mathrm{s}<.01\right)$. Collinearity did not appear to be a problem in either of the models; the largest variance inflation factor across both models was 2.31 (Kleinbaum et al., 1998). The first two independent variables, Deviant Subsistence Strategies and Substance Use, are not significantly related to Arrest for a More Serious Offense. However, Deviant Subsistence Strategies is marginally related, and Substance Use is significantly positively related, to Arrest for a Less Serious Offense.

The findings for the Gang variable are mixed. Gang-involved youths are no more likely than non-involved youths to be arrested for either type of offense. Nonetheless, multiplicative odds ratios $\left(\mathrm{e}^{\mathrm{B}}\right)$ indicate that, after controlling for the remaining variables in the multivariate models, gang members are 1.77 time more likely than non-involved youths to be arrested for a more serious offense; gang members are also marginally more likely than non-involved youths to be arrested for a less serious offense.

Results for the fourth variable, Prior Arrests, indicate that youths who had been arrested prior to running away from home are 3.62 and 2.36 times more likely to experience a first post-run arrest for a more serious and less serious offense, respectively. In addition, the quadratic age term, $\mathrm{Age}^{2}$, is statistically significant in the models for both dependent variables. The estimated probability of a first post-run arrest (for both models) increases until age 15 then declines thereafter (plot not shown). The sixth variable, Prior Physical Abuse, is not statistically significant in either of the models. In addition, Age on Own is marginally significant in the model predicting Arrest for a More Serious Offense and not statistically significant in the model predicting Arrest for a Less Serious Offense. The eighth variable, On the Street, is not significant in the model predicting Arrest for a More Serious Offense, but it is marginally significant in the model predicting Arrest for a Less Serious Offense. Youths who spent time directly on the street are 1.56 times more likely to be arrested for a less serious offense than are youths who did not spend time directly on the street. 
Table 1. Event History Analysis Results for Predicting the Likelihood of a First Post-run Arrest

\begin{tabular}{|c|c|c|c|c|}
\hline \multirow{3}{*}{ Independent Variables } & \multicolumn{4}{|c|}{ Type of Offense } \\
\hline & \multicolumn{2}{|c|}{ More Serious } & \multicolumn{2}{|c|}{ Less Serious } \\
\hline & $\mathrm{B}$ & $\mathrm{e}^{\mathrm{B}}$ & $\mathrm{B}$ & $\mathrm{e}^{\mathrm{B}}$ \\
\hline Deviant Subsistence Strategies & .10 & 1.11 & $.27+$ & 1.30 \\
\hline Substance Use & -.01 & .99 & $.14^{*}$ & 1.14 \\
\hline \multicolumn{5}{|l|}{ Gang } \\
\hline \multicolumn{5}{|l|}{ No Involvement (Reference) } \\
\hline Involved & .12 & 1.13 & .32 & 1.37 \\
\hline Member & $.57^{*}$ & 1.77 & $.45+$ & 1.56 \\
\hline Prior Arrests & $1.29 * *$ & 3.62 & $.86^{* *}$ & 2.36 \\
\hline Age & .10 & 1.10 & .06 & 1.06 \\
\hline $\mathrm{Age}^{2}$ & $-.05^{* *}$ & .95 & $-.03^{*}$ & .97 \\
\hline Prior Physical Abuse & .08 & 1.09 & .04 & 1.05 \\
\hline Age on Own & $-.08+$ & .92 & .08 & 1.08 \\
\hline On the Street & .21 & 1.23 & $.45+$ & 1.56 \\
\hline Race (1 = Non-White) & $.40^{*}$ & 1.49 & $-.55^{*}$ & .58 \\
\hline Gender ( 1 = Male) & $.50 *$ & 1.65 & $-.61^{*}$ & .55 \\
\hline Race by Gender & & & $1.03^{* *}$ & 2.81 \\
\hline Constant & $-3.04^{* *}$ & .05 & $-2.36^{* *}$ & .09 \\
\hline
\end{tabular}

$N=1761$ person-year observations. $+p<.10 ;{ }^{*} p<.05 ;{ }^{* *} p<.01$ for two-tailed tests. $\mathrm{G}^{2}[-2 \log$ likelihood $]=70.88, d f=12, p<.01$ for model predicting arrest for a more serious offense; $\mathrm{G}^{2}=74.05, d f=13, p<.01$ for model predicting arrest for a less serious offense. 
Finally, both Race and Gender-but not the Race by Gender interaction-are statistically significant in the model predicting Arrest for a More Serious Offense. Multiplicative odds ratios $\left(e^{\mathrm{B}}\right)$ indicate that, after controlling for the remaining variables in the model, non-whites and males are 1.49 and 1.65 times more likely than whites and females, respectively, to experience a fist post-run arrest for a more serious offense.

However, the Race by Gender interaction is statistically significant in the model predicting Arrest for a Less Serious Offense. Table 2 presents information to facilitate interpretation of the interaction effect. Cells in the first two rows and columns contain the estimated probabilities of arrest for a less serious offense by race and gender, and cells in the third row and column provide statistical comparisons for race-gender combinations. ${ }^{6}$ White females are more likely than non-white females $(p=.03)$ and white males $(p=.01)$ to be arrested for a less serious offense (estimated probabilities of .11, .07, and .07). Non-white males are somewhat more likely than white males $(p=.07)$ and not significantly more likely than nonwhite females $(p=.16)$ to be arrested for a less serious offense (estimated probabilities of. 10, .07, and .07).

Table 2. Estimated Probabilities of Arrest for a Less Serious Offense and Statistical Comparisons by Race and Gender

\begin{tabular}{lccc}
\hline & $\begin{array}{c}\text { White } \\
(\mathrm{W})\end{array}$ & $\begin{array}{c}\text { Non-White } \\
(\mathrm{N})\end{array}$ & $\begin{array}{c}\text { Statistical } \\
\text { Comparison }^{\mathrm{a}}\end{array}$ \\
\hline Female (F) & .11 & .07 & $\begin{array}{c}\text { WF vs. NF } \\
p=.03\end{array}$ \\
Male (M) & .07 & .10 & $\begin{array}{c}\text { WM vs. NM } \\
p=.07\end{array}$ \\
$\begin{array}{l}\text { Statistical } \\
\text { Comparison }\end{array}$ & WF vs. WM & NF vs. NM \\
$p=.01$ & $p=.16$ & \\
\hline
\end{tabular}

a. $\mathrm{WF}=$ white female, $\mathrm{NF}=$ non-white female, $\mathrm{WM}=$ white male, and $\mathrm{NM}=$ nonwhite male.

Statistical comparisons are based on simple slopes of race and gender using the procedures outlined in Aiken and West (1991). 


\section{Discussion and Conclusion}

The present study examined the contributions of race and gender to the likelihood of a first post-run arrest for a more serious and less serious offense in a sample of homeless and runaway youths from four Midwestern states. It was hypothesized that race and gender would interact so that the likelihood of a first post-run arrest for a more serious and less serious offense would be highest for non-white males and non-white females, respectively. Event history analysis was used to test the hypotheses, and other potentially confounding factors were controlled (deviant subsistence strategies, substance use, gang involvement and membership, prior arrests, age, prior physical abuse, age on own, and spending time on the street).

The hypotheses about the interaction of race and gender were not supported by the data. For the model predicting arrest for a more serious offense, the interaction of race and gender was not statistically significant, which suggests that non-white males did not have an increased risk of arrest relative to all other youths. Nevertheless, the main effects of race and gender were statistically significant, which indicated that non-whites were more likely than whites, and males were more likely than females, to be arrested for a more serious offense. The effects of race and gender were significant after controlling for criminal propensity variables (deviant subsistence strategies, substance use, gang involvement and membership, and prior arrests), and this suggests that some level of police discretion may be involved in arrests for more serious offenses. Thus, it seems that among homeless and runaway youths, both males and non-whites may be viewed as symbolic assailants.

For the model predicting arrest for a less serious offense, the interaction of race and gender was statistically significant, and the results indicated that white females were more likely than non-white females and white males to be arrested. Given that the interaction of race and gender was statistically significant after controlling for criminal propensity variables, it is plausible that, as with the more serious offenses, some level of police discretion may be involved in arrests for less serious offenses. This finding was the opposite of what was hypothesized and what has been found in previous research. Nonetheless, the hypothesized mechanisms - paternalism and racial biases - may be at work for these homeless and runaway females. Some researchers have suggested that young females are disproportionately arrested for status offenses because of paternalistic attitudes on the part of law enforcement officials. It has been argued that law enforcement officials are concerned about the sexual propriety of young females and "must be controlled and 'protected' from the 
temptations of the street" (Chesney-Lind, 1977, p. 126). It is possible that law enforcement officials are more likely to arrest white females in order to protect them from the hazards of the streets whereas they are more likely to let non-white females fend for themselves.

With respect to the confounding factors, we found that deviant subsistence strategies were not significantly related to the likelihood of arrest for a more serious offense and were only marginally related to arrest for a less serious offense. This finding contradicts the results obtained by Hagan and McCarthy (1994) who found that the number of times that acts of delinquency occurred was positively related to police sanctions. The results of our study might be due to problems with the deviant subsistence strategies measure. In particular, it measures variation in a limited number of types of deviant subsistence strategies, and it ignores the number of times that each strategy was used (unlike in Hagan and McCarthy's study (1994)). Research evidence suggests that the number of times that acts of delinquency occur varies significantly among homeless and runaway youths (Hagan \& McCarthy, 1994, 1997); thus, future research should include a measure of deviant subsistence strategies that better captures this variation. ${ }^{7}$

Moreover, substance use was not significantly related to the likelihood of arrest for a more serious offense, but it was positively related to arrest for a less serious offense. This finding is consistent with the results of a study of homeless adults in which substance use was related to the likelihood of arrest for minor and substance-related crimes but not for major crimes (Desai et al., 2000). Substance use might be related to the likelihood of arrest for a less serious offense for at least two reasons. First, the youths might be arrested for public intoxication or drug use. Second, public intoxication or drug use increases the chances of being seen by law enforcement officials and arrested for running away from home or other less serious offenses (Desai et al., 2000).

Furthermore, gang involved youths were no more likely than noninvolved youths to be arrested for either type of offense, and gang members were marginally more likely than non-involved youths to be arrested for a less serious offense. These findings contradict the results of other studies (Donnermeyer et al., 1996; Yoder et al., 2003) because the previous studies examined bivariate-and not multivariate-relationships (the bivariate relationships in this study were statistically significant [results not shown]). Nonetheless, we found that gang members were more likely to be arrested for a more serious offense, which could reflect either more involvement in serious criminal activities and/or law enforcement perceptions of gang members as criminally-prone symbolic assailants. 
In addition, we found that arrests prior to running away from home for the first time was a significant predictor of the likelihood of arrest for both types of offenses. This finding is consistent with previous research that suggests the importance of prior arrests in the likelihood of arrests among youths (Sealock \& Simpson, 1998). We also found a curvilinear relationship between age and the likelihood of arrest for both types of offenses, and this is similar to findings in other studies (e.g., Hirschi \& Gottfredson, 1983).

In contrast, physical abuse prior to running away from home was not significantly related to the likelihood of arrest. Hagan and McCarthy (1994) failed to find a direct relationship between childhood physical maltreatment and police sanctions; however, they found an indirect relationship via homelessness (current homelessness and number of runaway episodes). A similar mechanism is most likely at work in this study because the relationship between prior physical abuse and the likelihood of arrest is statistically significant at the bivariate level (results not shown). The interaction of prior physical abuse and prior arrests was not statistically significant; thus, we failed to find evidence for street crime amplification (Hagan \& McCarthy, 1997).

Moreover, the age when respondents are first on their own is marginally related to arrest for a more serious offense, but it is not significantly related to arrest for a less serious offense. The relationship between age first on their own and arrest for a more serious offense is consistent with research by Baron and Hartnagel (1998) and McCarthy and Hagan (1992a, 1992b), which suggests that time on the street and criminal behavior are positively related. In addition, spending time directly on the street is not significantly related to arrest for a more serious offense, but it is marginally related to arrest for a less serious offense. The relationship between spending time directly on the street and arrest for a less serious offense is consistent with research by Hagan and McCarthy (1994) who reported a statistically significant positive relationship between homelessness and police sanctions. Snow, Baker, and Anderson (1989) argued that length of time on the street (measured by age first on their own in h s study) and being on the street increases the likelihood of being seen by the police and, hence, arrested. The results of this study partially support their argument. In particular, age first on their own plays a role in arrests for more serious offenses, and being on the street plays a role in arrests €or less serious offenses (in the presence of other factors such as deviant subsistence strategies, substance use, gang involvement and membership, prior arrests, gender, and race). 
Finally, we failed to find evidence that being on the street and age might interact with each other and with race and gender to affect the likelihood of arrest. Thus, the effect of being on the street is not amplified by age, race, or gender. Similarly, the curvilinear relationship between age and the likelihood of arrest is the same regardless of race or gender, which is consistent with the conclusions of Hirschi and Gottfredson (1983).

Overall, it appears that police discretion plays an important role in the likelihood of a first post-run arrest among these homeless and runaway youths. After controlling for criminal propensity variables and prior arrests, the likelihood of arrest was influenced by age on own (for a more serious offense), spending time on the street (for a less serious offense), race, and gender. In contrast, it seems that criminal propensity plays a less important role in the likelihood of arrest, especially for a more serious offense. Whereas neither deviant subsistence strategies nor substance use were related to arrests for a more serious offense, both were related to arrests for a less serious offense. However, conclusions about the relative contributions of police discretion and criminal propensity also depend on the roles of gang membership and prior arrests; these variables could reflect varying degrees of both police discretion and criminal propensity.

Some weaknesses of the present study should be acknowledged. First, the results may not generalize to youths in non-runaway/homeless populations or to homeless and runaway youths in other parts of the country. Although the study was based on a sample of youths from several Midwestern cities, research has demonstrated that characteristics of runaways (such as gender, race/ethnicity, living on the street, and physical abuse) differ by region of the country (Thompson, Maguin, \& Pollio, 2003), and these differences might yield disparate results in samples of runaway and homeless youths in other parts of the country. Second, the analyses were based on retrospective, single-person reports of arrest history and other variables, and the results are subject to the usual recall and single-reporter biases. Third, we restricted the reporting of arrests to the first and the four most recent ones, and as a result, we did not know when the first post-run arrest occurred among youths who were arrested more than five times. Obviously, a more complete arrest history gathered prospectively would have been ideal for these analyses.

Fourth, we are not certain about the relative timing of being on the street and being arrested within a given year. It was assumed that being on the street preceded arrests, but it may be that some of the youths were arrested and after being released, ended up on the street at some point. Fifth, our Age on Own measure was a likely weak proxy for time on the street because the youths in this sample may have returned home, lived 
with other relatives, lived with friends, or spent time in institutions since running away from home for the first time. Finally, our deviant subsistence strategies, substance use, and gang involvement and membership measures were weak because they are not linked to time, and they were included under the unlikely assumption that deviant subsistence strategies, substance use, and gang involvement and membership were stable over time.

The results of the present study should be interpreted with caution, and they await further replication in other studies of homeless and runaway youths. It is plausible that the relationship of race and gender with the likelihood of arrest is due to one of several other confounding factors that were not measured and not included in the analyses. Previous research suggests that the demeanor of the suspect (Piliavin \& Briar, 1964; Smith et al., 1984; Visher, 1983), the physical appearance of the suspect (Piliavin \& Briar, 1964), victim characteristics such as race and age (D'Alessio \& Stolzenberg, 2003; Smith et al., 1984), relationship between suspect and victim (D'Alessio \& Stolzenberg, 2003), and victim request for arrest (Black \& Reiss, 1970; Lundman et al., 1978; Smith et al., 1984; Visher, 1983) are also influential in the decision to arrest.

\section{Notes}

1. Five of the youths in the MHRAP were arrested more than five times in their lives and had been arrested prior to running away from home for the first time. We did not know when their first post-run arrest occurred, so we conservatively estimated that they had their first post-run arrest at the age at which they first ran away from home. Excluding these cases from subsequent analyses did not change the results substantively.

2. Centering means that each youth's age was recoded by subtracting from it the average age of all youths in the sample. For the person-year data set (see Analytic Strategy section), the average age was 14. Thus, the centered value of the age variable for someone who is 16 years old would be 16-14 = 2 (Kleinbaum et al., 1998).

3. Age and Age on Own were highly correlated $(r=.70, p<.0001$, in the person-year data sets); however, both variables were included in the models because they were conceptually distinct and because their presence did not substantially change the coefficient estimates or their standard errors for any other variables in the models. 
4. This "competing risks" assumption means that in the data set constructed for less serious offenses, youths who were first arrested for a more serious offense contributed one observation per year until they were arrested, at which time their arrest outcome was coded as zero (i.e., they were not arrested for a less serious offense). A similar procedure was followed for the data set constructed for more serious offenses.

5. All of the continuous variables (Deviant Subsistence Strategies, Substance Use, Age, Age ${ }^{2}$, Prior Physical Abuse, and Age on Own) were centered (see Footnote 1). This was done for two reasons: (1) to reduce collinearity between main and interaction effects involving Age, $\mathrm{Age}^{2}$, and Prior Physical Abuse (Aiken \& West, 1991) and (2) to maintain consistency in the coding of all the continuous variables.

6. Estimated probabilities were obtained by substituting appropriate values of race $(0=$ white, $1=$ non-white $)$ and gender $(0=$ female, $1=$ male $)$ as well as the mean values of the remaining variables into the equation given in Table 1 . These values were used to compute the log-odds of arrest (LOA), and then the estimated probability of arrest was computed as $1 /\left(1+\mathrm{e}^{(-1 * \mathrm{LOA})}\right)$. The statistical comparisons are based on simple slopes of race and gender using the procedures outlined in Aiken and West (1991). Further information is available on request from the first author.

7. We are grateful to an anonymous reviewer who noted the problems with the deviant subsistence strategies measure and suggested this interpretation of our finding.

\section{References}

Aiken, L. S., and S. G. West (1991). Multiple Regression Testing and Interpreting Interactions. Newbury Park, CA: Sage Publications.

Allison, P. D. (1984). Event History Analysis: Regression for Longitudinal Data. Sage University Paper series on Quantitative Applications in the Social Sciences, series no. 07-046. Newbury Park, CA: Sage Publications.

Baron, S. W., and T. F. Hartnagel (1998). "Street Youth and Criminal Violence." Journal of Research in Crime and Delinquency 35:166-192.

Black, D. J., and A. J. Reiss (1970). "Police Control of Juveniles." American Sociological Review 35:63-77. 
Blumstein, A., and E. Graddy (1982). "Prevalence and Recidivism in Index Arrests: A Feedback Model." Law and Society Review 16:265-290.

Chesney-Lind, M. (1977). "Judicial Paternalism and the Female Status Offender: Training Women to Know Their Place." Crime \& Delinquency 23:121-130.

Chesney-Lind, M., and R. G. Shelden (1998). Girls, Delinquency, and Juvenile Justice (2nd ed.). Belmont, CA: West/Wadsworth.

Conley, D. J. (1994). “Adding Color to a Black and White Picture: Using Qualitative Data to Explain Racial Disproportionality in the Juvenile Justice System." Journal of Research in Crime and Delinquency 31:135-148.

Curry, G. D., S. H. Decker, and A. Egley (2002). "Gang Involvement and Delinquency in a Middle School Population." Justice Quarterly 19:275-292.

D'Alessio, S. J., and L. Stolzenberg (2003). "Race and the Probability of Arrest." Social Forces 81:1381-1397.

Desai, R. A., J. Lam, and R. A. Rosenheck (2000). “Childhood Risk Factors for Criminal Justice Involvement in a Sample of Homeless People with Mental Illness." The Journal of Nervous and Mental Disease 188:324-332.

Donnermeyer, J. F., R. W. Edwards, E. L. Chavez, and F. Beauvais (1996). “Involvement of American Indian Youths in Gangs." Free Inquiry in Creative Sociology 24:167-174.

Dukes, R. L., R. O. Martinez and J. A. Stein (1997). "Precursors and Consequences of Membership in Youth Gangs." Youth E Society 29:139-165.

Engen, R. L., S. Steen, and G. S. Bridges (2002). “Racial Disparities in the Punishment of Youth: A Theoretical and Empirical Assessment of the Literature." Social Problems 49:194-220.

Hagan, J., and B. McCarthy (1994). "Double Jeopardy: The Abuse and Punishment of Homeless Youth." In Inequality, Crime, and Social Control., G. S. Bridges and M. A. Myers, eds. Boulder, CO: Westview Press.

Hagan, J., and B. McCarthy (1997). Mean Streets: Youth Crime and Homelessness. New York: Cambridge University Press. 
Hindelang, M. J. (1978). “Race and Involvement in Common Law Personal Crimes." American Sociological Review 43:93-109.

Hirschi, T., and M. Gottfredson (1983). "Age and the Explanation of Crime." American Journal of Sociology 89:552-584.

Horowitz, R., and A. E. Pottieger (1991). "Gender Bias in Juvenile Justice Handling of Seriously Crime-Involved Youths." Journal of Research in Crime and Delinquency 28:75-100.

Huizinga, D., and D. S. Elliott (1987). "Juvenile Offenders: Prevalence, Offender Incidence, and Arrest Rates by Race." Crime \& Delinquency 33:206-223.

Johnstone, J.W.C. (1983). "Recruitment to a Youth Gang." Youth E Society 14:281-300.

Kaufman, J. G., and C. S. Widom (1999). “Childhood Victimization, Running Away, and Delinquency." Journal of Research in Crime and Delinquency 36:347-370.

Kipke, M. D., J. B. Unger, S. O'Connor, R. F. Palmer, and S. R. LaFrance (1997). "Street Youth, Their Peer Group Affiliation and Differences According to Residential Status, Subsistence Patterns, and Use of Services." Adolescence 32:655-669.

Kleinbaum, D. G., L. L. Kupper, K. E. Muller, and A. Nizam (1998). Applied Regression Analysis and Other Multivariable Methods (3rd ed.). Pacific Grove, CA: Brooks/Cole.

Krisberg, B., I. Schwartz, G. Fishman, Z. Eisikovits, E. Guttman, and K. Joe (1987). "The Incarceration of Minority Youth." Crime and Delinquency 33:173-205.

Lundman, R. J., R. E. Sykes, and J. P. Clark (1978). “Police Control of Juveniles: A Replication." Journal of Research in Crime and Delinquency 15:74-91.

McCarthy, B., and J. Hagan (1992a). "Mean Streets: The Theoretical Significance of Situational Delinquency Among Homeless Youths." American Journal of Sociology 98:597-627.

McCarthy, B., and J. Hagan (1992b). "Surviving on the Street: The Experiences of Homeless Youth." Journal of Adolescent Research 7:412-430. 
McCarthy, B., and J. Hagan (1995). "Getting into Street Crime: The Structure and Process of Criminal Embeddedness." Social Science Research 24:63-95.

McCord, J., C. S. Widom, and N. A. Crowell (2001). Juvenile Crime, Juvenile Justice. Washington, DC: National Academy Press.

Piliavin, I., and S. Briar (1964). "Police Encounters with Juveniles." American Journal of Sociology 70:206-214.

Sealock, M. D., and S. S. Simpson (1998). "Unraveling Bias in Arrest Decisions: The Role of Juvenile Offender Type-Scripts." Justice Quarterly 15:427-457.

Shaffer, D., and C.L.M. Caton (1984). Runaway and Homeless Youth in New York City: A Report to the Ittleson Foundation. New York: Ittleson Foundation.

Singer, J. D., and J. B. Willett (1993). "It's About Time: Using Discrete-Time Survival Analysis to Study Duration and the Timing of Events." Journal of Educational Statistics 18:155-195.

Skolnick, J. H. (1966). Justice Without Trial: Law Enforcement in a Democratic Society. New York: Wiley.

Smith, D. A., C. A. Visher, and L. A. Davidson (1984). "Equity and Discretionary Justice: The Influence of Race on Police Arrest Decisions." Journal of Criminal Law \& Criminology 75:234-249.

Snow, D. A., S. G. Baker, and L. Anderson (1989) "Criminality and Homeless Men: An Empirical Assessment." Social Problems 36:532-549.

Straus, M. A. (1979). "Measuring Intrafamily Conflict and Violence: The Conflict Tactics (CT) Scale." Journal of Marriage and the Family 41:75-88.

Thompson, S. J., E. Maguin, and D. E. Pollio (2003). "National and Regional Differences Among Runaway Youth Using Federally-Funded Crisis Services." Journal of Social Services Research 30:1-17.

Visher, C. A. (1983). "Gender, Police Arrest Decisions, and Notions of Chivalry" Criminology 21:5-28.

Whitbeck, L. B., and R. L. Simons (1993). “A Comparison of Adaptive Strategies and Patterns of Victimization Among Homeless Adolescents and Adults." Violence and Victims 8:135-152. 
Wordes, M., and T. S. Bynum (1995). "Policing Juveniles: Is There Bias Against Youths of Color?" In Minorities in Juvenile Justice., K. K. Leonard, C. E. Pope, and W. H. Feyerherm, eds. Thousand Oaks, CA: Sage Publications.

Yoder, K. A., L. B. Whitbeck, and D. R. Hoyt (2003). “Gang Involvement and Membership Among Homeless and Runaway Youth." Youth \& Society 34:441-467.

Zimring, F. E. (1998). American Youth Violence. New York: Oxford University Press. 